\title{
HYBRID BACILLUS ENDO-(1-3,1-4)- $\beta$-GLUCANASES: CONSTRUCTION OF RECOMBINANT GENES AND MOLECULAR PROPERTIES OF THE GENE PRODUCTS
}

\author{
by
RAINER BORRISS ${ }^{1,2)}$, OLE OLSEN ${ }^{2)}$, KARL KRISTIAN THOMSEN ${ }^{2)}$ and DITER VON WETTSTEIN ${ }^{2)}$ \\ 1)Sektion Nahrungsgüterwirtschaft und Lebensmitteltechnologie, \\ Bereich Mikrobiologie, Humboldt-Universitāt Berlin, \\ Warschauer Strasse 43-44, DDR-1017 Berlin \\ ${ }^{2)}$ Department of Physiology, Carlsberg Laboratory, \\ Gamle Carlsberg Vej 10, DK-2500 Copenhagen Valby
}

Keywords: $\beta$-glucanase, hybrid genes, Bacillus, in vitro recombination

Hybrid $\beta$-glucanase genes were constructed by the reciprocal exchange of the two halves of the isolated $\beta$-glucanase genes from Bacillus amyloliquefaciens and B. macerans. The $\beta$-glucanase hybrid enzyme 1 (HI) contains the 107 amino-terminal residues of mature B. amyloliquefaciens $\beta$-glucanase and the 107 carboxyl-terminal amino acid residues of $B$. macerans $\beta$-glucanase. The reciprocal $\beta$-glucanase hybrid enzyme $2(\mathrm{H} 2)$ consists of the 105 amino-terminal residues from the B. macerans enzyme and the carboxyl-terminal 107 amino acids from B. amyloliquefaciens. The biochemical properties of the two hybrid enzymes differ significantly from each other as well as from both parental $\beta$-glucanases.

Hybrid $\beta$-glucanase $\mathrm{H} 1$ exhibits increased thermostability in comparison to other $\beta$-glucanases, especially in an acidic environment. This hybrid enzyme has maximum activity between $\mathrm{pH} 5.6$ and 6.6, whereas the pH-optimum for enzymatic activity of $\mathrm{B}$. amyloliquefaciens $\beta$-glucanase was found to be at $\mathrm{pH} 6$ to 7 and for $\mathrm{B}$. macerans at pH 6.0 to 7.5. Hybrid enzyme 1 being more heat stable than both parental enzymes represents a case of intragenic heterosis.

Hybrid $\beta$-glucanase 2 (H2) was found to be more thermolabile than the naturally occurring $\beta$-glucanases it was derived from and the pH-optimum for enzymatic activity was determined to be between $\mathrm{pH} 7$ and $\mathrm{pH} 8$.

\section{INTRODUCTION}

The mixed linked (1-3,1-4)- $\beta$-glucans constitute the major part of the endosperm cell walls of cereals like oat and barley. They can cause severe problems in the brewing industry such as reduced yield of extract and lowered rates of wort separation or beer filtration. Remaining $\beta$-glucans in the finished beer may lead to formation of hazes and gelatinous precipitates (11). Barley (1-3,1-4)- $\beta$-glucanases (EC 3.2.1.73) are synthesized in the scutellum and the aleurone layer during the early stages of germi-

Abbreviations: $\mathrm{a} a$ = amino acids; $\mathrm{amp}=$ ampicillin; $\mathrm{bgl}=\beta$-glucanase gene; $\beta$-glucan $=(1-3,1-4)-\beta$-D-glucan; PAGE = polyacrylamide gel electrophoresis; $\mathrm{SDS}=$ sodium dodecyl sulfate; tet = tetracycline; $\mathrm{SP}=$ signal peptide. 
nation (21). However, a large proportion of the malt $\beta$-glucanase is irreversibly heat inactivated during kilning and the remaining activity is rapidly destroyed during mashing (18). Therefore, thermostable (1-3,1-4)- $\beta$-glucanases of fungal or bacterial origin are often added during mashing.

The best characterized bacterial (1-3,1-4)- $\beta$ glucanases are those from Bacillus subtilis and B. amyloliquefaciens and the genes encoding these enzymes have been cloned and sequenced $(6,9,14,23)$. It has recently been shown that the $\beta$-glucanase from $B$. macerans is more thermostable than the $B$. subtilis and $B$. amyloliquefaciens enzymes $(4,5)$. The B. macerans $\beta$-glucanase gene has been cloned (7) and its nucleotide sequence determined (BoRRISs et al., in prep.). Comparison of the derived amino acid sequence with the derived sequences of $B$. subtilis and B. amyloliquefaciens discloses an overall homology of $70 \%$.
In the present report we describe the construction of hybrid bacterial $\beta$-glucanase genes encoding active enzymes that degrade barley $\beta$-glucan and lichenan. Analyses of the biochemical properties of the hybrid enzymes in comparison to the parental $\beta$-glucanases are presented.

\section{MATERIALS AND METHODS}

\subsection{Strains, plasmids and growth media}

E. coli DH5 $\alpha$ cells: $\mathrm{F}$, endA1, hsd $R 17\left(\mathrm{r}_{\mathrm{k}}\right.$, $\mathrm{m}_{\mathrm{k}}{ }^{+}$), supE44, thi1, $\lambda$, recA1, gyrA96, relA1, o80dlac $Z, \triangle M 15(12)$ were used for propagation of plasmids and for expression of $\beta$-glucanase genes. The vectors comprised pBR322 (2) and pUC19 (30). The recombinant plasmid pEGl (6) carries an insert with the B. amyloliquefaciens $\beta$-glucanase gene and pUC13-Mac carries a DNA insert with the $\beta$-glucanase gene from $B$. macerans which is identical to the insert of

\section{CONSTRUCTION OF pUC13-H1}

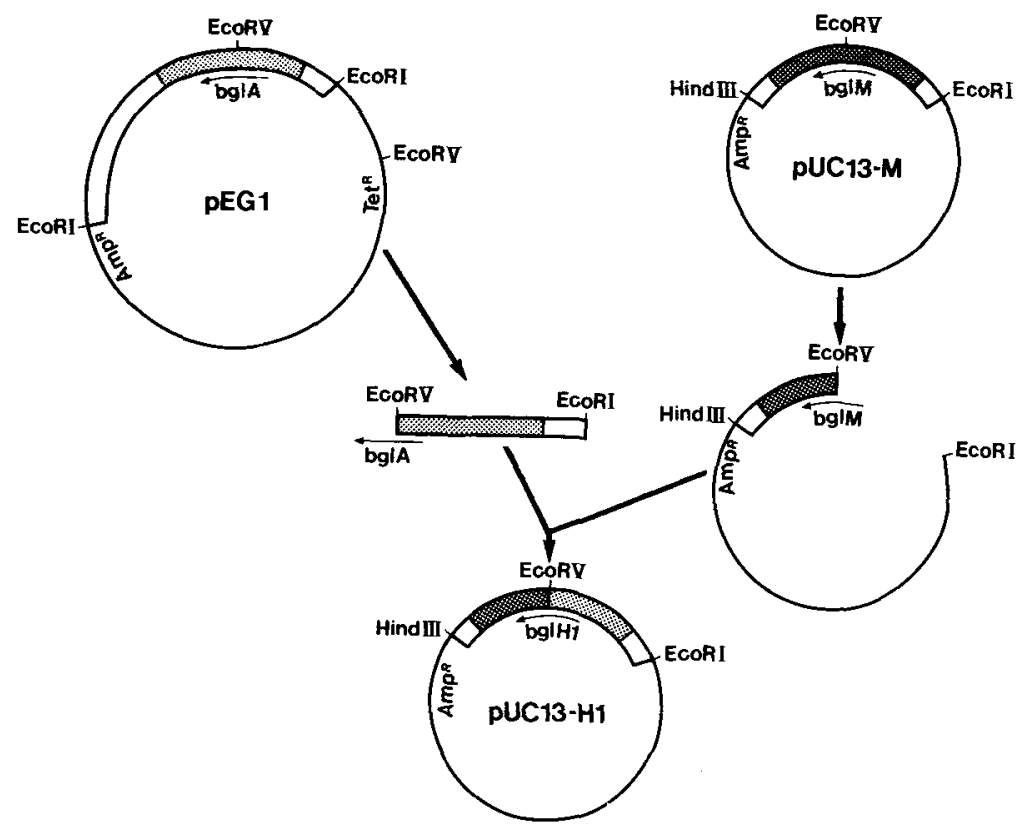

Figure 1. Construction of an E. coli expression and secretion vector containing the hybrid gene bgl-H 1 . bgl-A: $(1-3,1-4)-\beta$-glucanase gene from B. amyloliquefaciens. bgl-M: $(1-3,1-4)-\beta$-glucanase gene from $B$. macerans. For details, see section 2.5 . 
plasmid pUC19/34 (7). Media and growth conditions were as described previously (7).

\subsection{Enzymes and chemicals}

Radioactive nucleotides were from New England Nuclear, Boston, Massachusetts, USA. Restriction endonucleases, calf intestinal phosphatase and T4-DNA ligase were from Boehringer Mannheim, Mannheim, W. Germany. Modified T7-DNA polymerase (Sequenase $^{\mathrm{TM}}$ ) was from United States Biochemical Corporation, Cleveland, Ohio, USA. A Geneclean $^{\mathrm{TM}}$ kit was from BIO 101 Inc., La Jolla, California, USA. Barley $\beta$-glucan as well as a $\beta$-glucanase assay kit was purchased from Biocon, Boronia, Victoria, Australia. Lichenan was prepared from Cetraria islandica as described previously (3).

\subsection{Transformation}

E. coli cells were grown and prepared for transformation as described by LEDER BERG and COHEN (17) and the competent cells were stored frozen as described by THOMSEN (29).

\subsection{DNA purification}

Plasmid DNA was prepared from E. coli by the method of HATrORI and SAKAKI (13). Specific DNA fragments generated by restriction endonuclease digestion were separated by agarose gel electrophoresis and purified from the gel matrix using a Geneclean ${ }^{\mathrm{TM}}$ kit according to the manufacturer's recommendations.

\subsection{Construction of hybrid $\boldsymbol{\beta}$-glucanase genes}

The B. amyloliquefaciens and B. macerans $\beta$-glucanase genes, and proteins, are highly homologous. In the center of the genes is a unique EcoRV restriction site which was used as fusion point in the construction of hybrid $\beta$-glucanase genes.

Construction of pUC13-H1 (Fig. 1): An EcoRV fragment which contains the 5'-flanking region and the amino-terminal half coding region of the B. amyloliquefaciens B-glucanase gene was isolated from plasmid pEG1 (6) and ligated with the large EcoRV-EcoRI fragment from pUC13-M encoding the carboxyl-terminal half of the B. macerans enzyme thus generating plasmid pUC13-H1 carrying the hybrid gene bgl-H1. E. coli DH5a cells transformed with pUC13-H1 are resistant to ampicillin.

Construction of pUC19-H2 (Fig. 2): For construction of the reciprocal recombinant gene, the $B$. macerans $\beta$-glucanase gene was excised as an EcoRI-Pstl fragment from plasmid pUC13$M$ and recloned in pBR322 giving rise to plasmid pBR-MAC1 from which the small EcoRV fragment was purified and fused to the large EcoRV fragment from plasmid pEG1. With the insert in the correct orientation the plasmid is designated pEG-H2 and E. coli cells transformed with the plasmid were selected on medium containing tetracycline. The hybrid gene was excised from pEG-H2 as an EcoRI-BglII fragment and recloned in EcoRI-BamHI digested pUC19 to give plasmid pUC19-H2.

\subsection{DNA sequence determination}

Modified T7-DNA polymerase (Sequena$\mathrm{se}^{\mathrm{TM}}$ ) was used for nucleotide sequence determination around splice junctions of hybrid B-glucanase genes. The reactions were performed as described by ZHANG et al. (32).

\subsection{Enzyme purification and analysis}

For determination of thermostability of the hybrid enzyme $\mathrm{H} 1$ and parental enzymes $\mathrm{E}$. coli cells harbouring the plasmid pUC13-H1, the plasmids pEG1 and pUC13-M were grown in tryptone-yeast medium ( $10 \mathrm{~g}$ tryptone, $5 \mathrm{~g}$ yeast extract, $5 \mathrm{~g} \mathrm{NaCl}$ per l) at $37^{\circ} \mathrm{C}$ for 16 to 20 hours. The cells were lysed by sonication (Branson Sonifier) and after clearing of the lysate by centrifugation $\beta$-glucanase stability was analysed by incubation of the reaction mixture containing an aliquot of clarified lysate for various length of time at $65^{\circ} \mathrm{C}$ or $70^{\circ} \mathrm{C}$ followed by determination of residual $\beta$-glucanase activity.

Purification of $\beta$-glucanase from cell extracts as described in (7) has been used for the parental enzymes and hybrid enzyme H1. Due to low 
CONSTRUCTION OF pUC19-H2

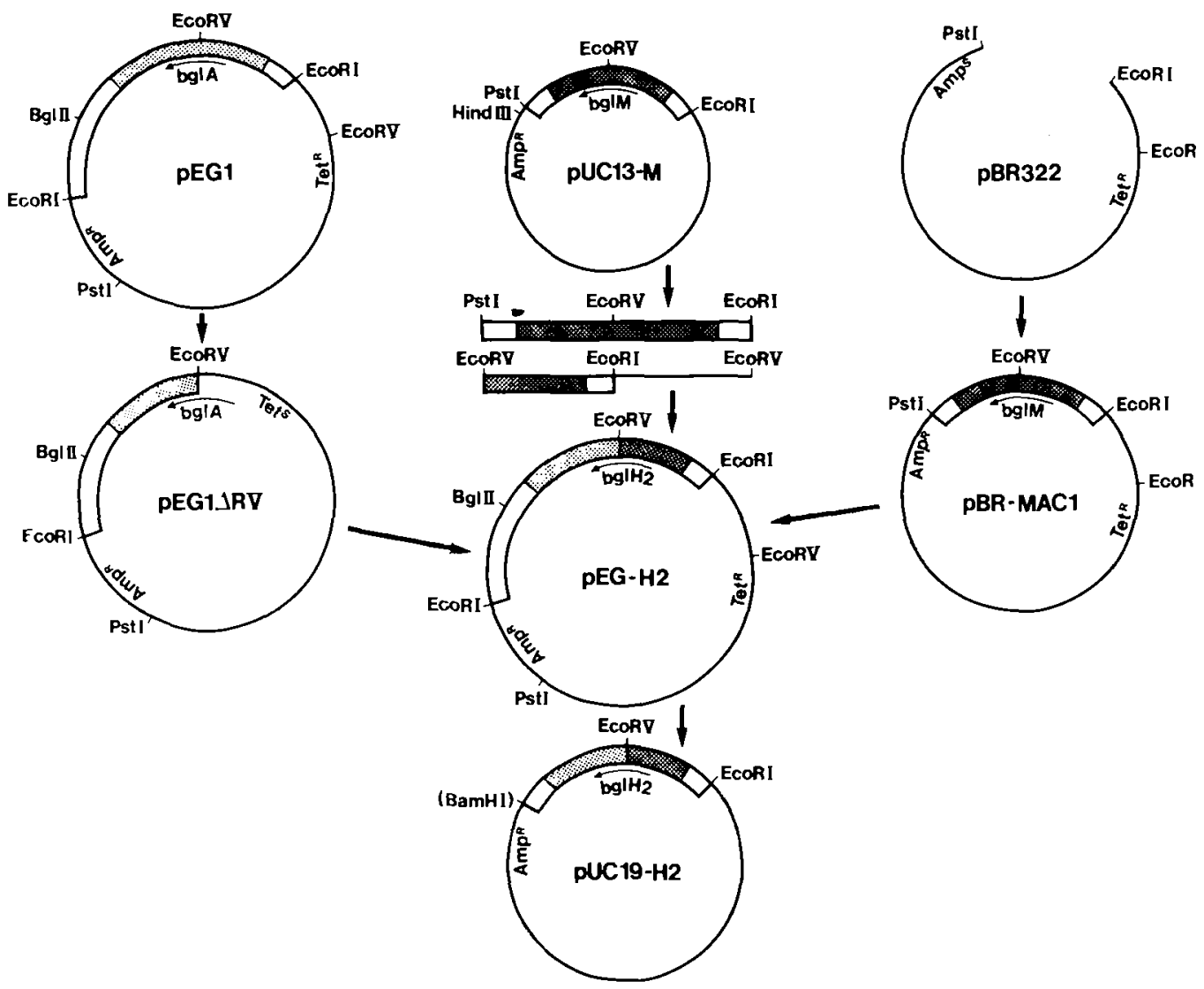

Figure 2. Construction of an E. coli expression and secretion vector containing the hybrid gene bgl-H2. bgl-A: $(1-3,1-4)-\beta-g l u c a n a s e$ gene from B. amyloliquefaciens. bgl-M: $(1-3,1-4)-\beta$-glucanase gene from B. macerans For details, see section 2.5 .

yield of $\mathrm{H} 2 \beta$-glucanase this enzyme was not purified to homogeneity. Ammonium sulphate precipitation of crude cell extracts enriched this $\beta$-glucanase to a specific activity of $10.4 \mathrm{U} / \mathrm{mg}$ $\left(10.4 \mu\right.$ mole glucose $\left.\mathrm{mg}^{-1} \cdot \mathrm{min}^{-1}\right)$. Protein concentration was determinated according to BRADFORD (8) using bovine serum albumin as stan- dard. Enzyme preparations were analysed by SDS-PAGE (16).

\section{B-glucanase assays:}

Method A: The reaction mixture consisted of 1 $\mathrm{ml} 0.5 \%(\mathrm{w} / \mathrm{v})$ lichenan or barley $\beta$-glucan in $4 \mathrm{C}$ mM Na-acetate buffer, pH 6.0, with or withou

Figure 3. Structure of the bgl-HI gene. a, Nucleotide sequence of the bgl-H 1 gene and derived amino acid sequence of the hybrid pre-protein consisting of the signal peptide and the amino-terminal of the B. amyloliquefaciens protein and the carboxyl-terminal half of the B. macerans $\beta$-glucanase. The EcoRV site used for splicing is indicated. An arrow indicates the signal peptidase cleavage site. b, Diagram of the bgl-Hl gene and details of the fusion region. SP: signal peptide. 


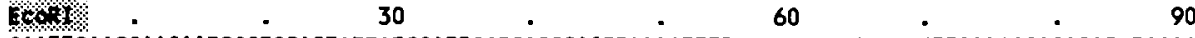

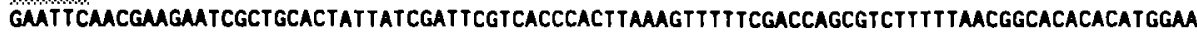

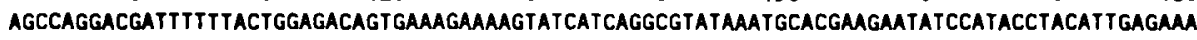
$210 \quad 210 \quad 240 \quad$ - 270

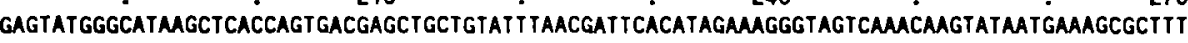

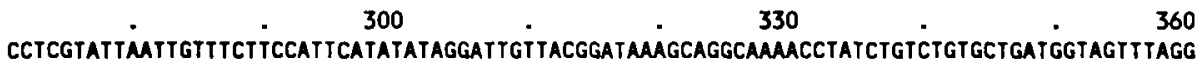

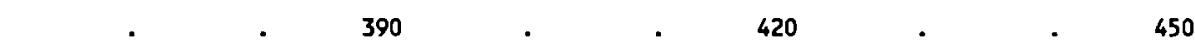

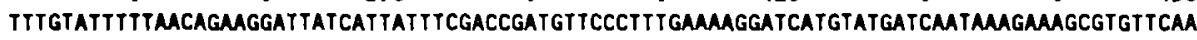
$\begin{array}{lllll}0 & 480 & 510 & 50 & 540\end{array}$ AMAGGGGGATGCTAACATGAMCGAGTGTTGCTAATTCTTGTCACCGGATTGTTIATGAGTTTGTGTGGGATCACTICTAGTGTTTCG MetLysArgValleuLouI leLeuValThrGlyLeuPhoMatSerLeuCysGlyI $\bullet$ ThrSerSerValSer 570 600 630 GCTCAMCAGGCGGATCGITTTTTGAACCTTITAACAGCTATAACTCCGGGTTATGGCMMMGCTGATGGTTACTCAAATGGAGATATG

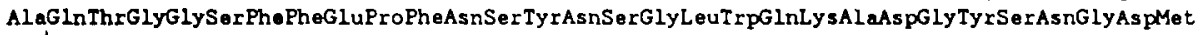
1

660

690

720

TITAMCTGCACT TGGCGTGCTMATAACGTCTCTATGACGTCATTAGGTGAMTGCGTTTGGCGCTGACAAGTCCGTCITATAACAAGTT PheAsnCy=ThrTrpArgAlaAsnAsnValSerMetThrSerLeuGlyGiuMetArgLeuAlaLeuThrSerProSerTyrAsnLys Phe

750

780

810

GACTGCGGGGAMCCGCTCGGTTCAACATATGGCTATGGACTTTATGAAGTCAGAATGAACCGGCTAMAAACACAGGGATTGTTTCA

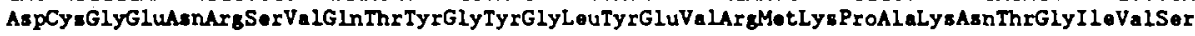

840

. 000870

900

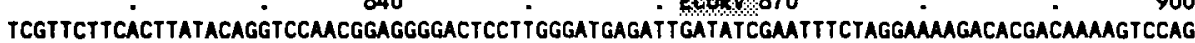
SerPhePheThrTyrThrGlyProThrGluGlyThrProTrpAspGluI LAspIleGluPheLeuGlyLysAspThrThrLys ValGln

960

990

TITAACTATTATACCATGGGGTTGGGGTCATGAAAAGGTTATCTCTCTTGGCTITGATGCATCAAGGGCTTCCATACCTATGCTTTC PheAsnTyrTyrThrAsnGlyValGlyGlyHisGluLys ValI

$1020 \quad$ - $\quad 1050$

$1050 \quad 1080$ GATTGGCAGCCAGgGTATATtAMATGGTATGTAGACGgTGTTITGAAACATACCGCCACCGCGAATAT TCCGAGTACGCCAGGCAAAATT

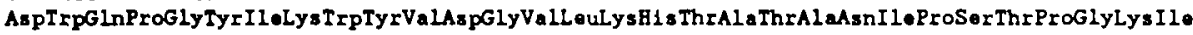

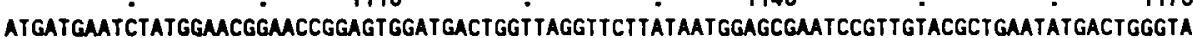
MetMotAsnLouTrpAsnGlyThrGlyValAspAspTrpLouGlySerTyrAsnGlyAlaAsnProLouTyrAleGluTyrAspTrpVal

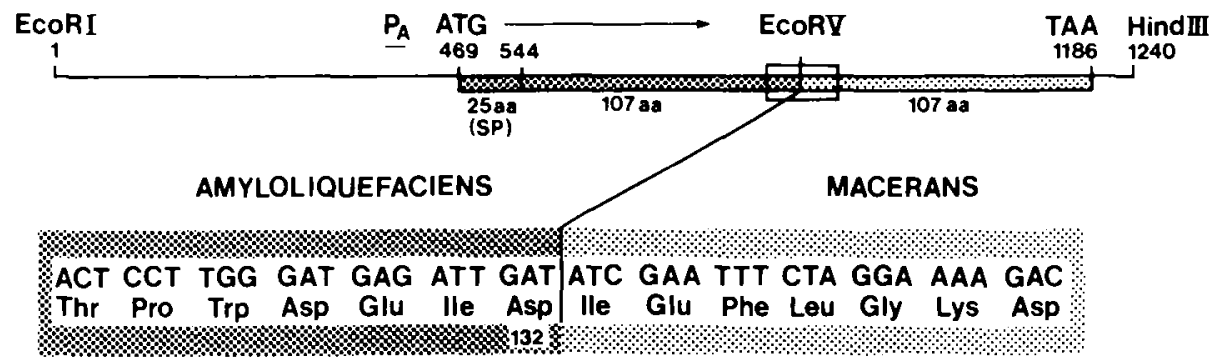


R. BorRISS et al.: Hybrid $\beta$-glucanases

a

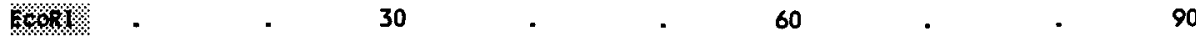
GAATTCCAGCTCGgataTACTATAATTACCCAGgTAAAATAT TCCAACACCGTGGCTCCATAACTTCGT TCATATITAAAATCATTIGG

$120 \quad 150 \quad . \quad 180$

AGGTGTATTATGAAAAGGÄGTCCTGTTTTACACTGGTGACCACATTTGCGTITTCTTTGATITTTTCTGTAAGCGCTTTAGCGGGGAGT MetLysLysLysSerCysPheThrLeuValThrThrPheAlaPhoSerLeuIlePheSerValSerAlaLeuAlaGlySer $210 \quad 240 \quad$ † 270 GIGTICTGGGAACCATTAAGTTATITIAATCCGAGTACATGGGAAAAGGAGATGGGTATTCCAATGGGGGGTGTTCAATTGCACATGG ValPheTrpGluProLeuSerTyrPheAsnProSerThrTrpGluLysAlaAspGlyTyrSerAsnGlyGlyValPheAsnCysThrTrp

330

360

CGTGCCAACAATGTTAATTTTACGAATGATGGAAAGCTCAAGCTGGGCTTAACGAGTTCTGCGTACAACAAATTTGACTGCGCGGAGTAC ArgAlaAsnAsnVaLAsnPheThrAsnAspGlyLy sLeuLy SLeuGlyLeuThrSerSerAlaTyrAsnLy SheAspCysAlaGiuTyr

390

450

CGATCAACGAACATTTACGGATACGgCCTGTACGAGgTCAGTATGAAGCCAGCCAAAAATACAGGAATTGTCTCATCCTIITTCACGTAT ArgSerThrAsnIleTyrGlyTyrGlyLeuTyrGluValSerMetLysProAlaLysAsnThrGlyIleValSerSerPhePheThrTyr

480 EoORV $510 \quad . \quad 540$

ACAGGACCTGCTCATGGCACACAATGGGATGAAATAGATATCGAATTTTTGgGaAAGGCACAACGAAGGT TCAATTTAACTATTATACA ThrGlyProAlaBisGlyThrGInTrpAspGluI leAspI leGluPheLeuGlyLysAspThrThrLysValGlnPheAsnTyrTyrThr

$570 \quad$. $600 \quad 630$

AATGGCGCAGGAAACCATGAGAAGT TCGCGGATCTCGGATITGATGCAGCCAATGCCTATCATACGTATGCGTTCGATTGGCAGCCAAAC AsnGlyAlaGlyAsnHisGluLy sPheAlaAspLeuGly PheAspAlaAlaAsnAlaTyrHi s ThrTyrAlaPheAspTrpGinProAsn

$660 \quad 690 \quad 720$

TCTATTAAATGGTATGTCGATGGGCAATTAAAACATACT GCAACAACCCAAATACCGGCAGCGCCGGGGAAAATCATGATGAATTTGTGG SerI leLysTrpTyrVaLAs pGlyGInLeuLysHis ThrAlaThrThrGlnIleProAlaAlaProGlyLysI leMetMetAsnLeuTrp

$750 \quad . \quad 780 \quad . \quad 810$

AATGGTACGgGTGTTGATGATIGGCTCGGTICCIACAATGGCGTAAAICCGATATACGCTCATTACGACTGGATGCGCTATAGAAAAAAA AsnGly ThrGlyValAspAspTrpLeuGlySerTyrAsnGlyVaLAsnProI leTyrAlaHis TyrAspTrpMetArgTyrArgLysLys

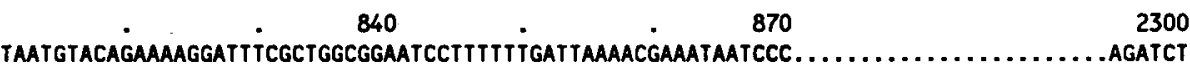

OSO

\section{b HYBRID GENE ENCODING(1-3,1-4)- $\beta$-GLUCANASE H2}

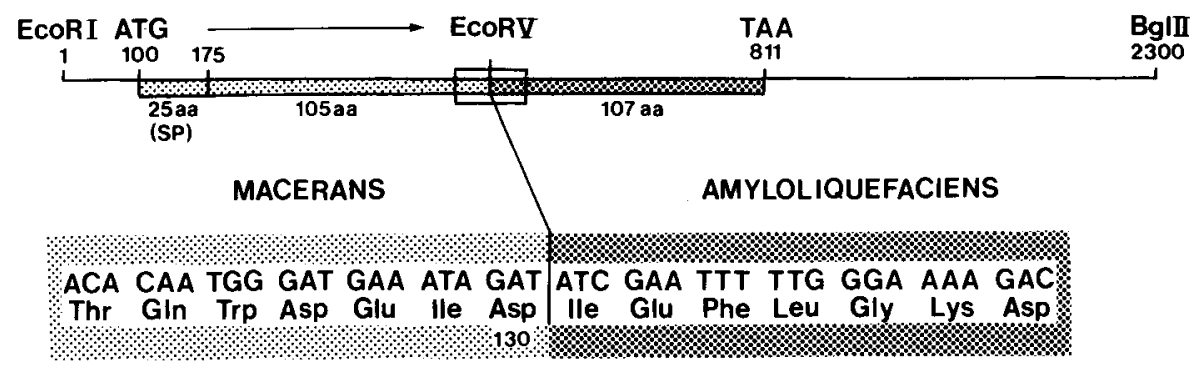

Figure 4. Structure of the bgl-H2 gene. a, Nucleotide of the bgl-H2 gene and derived amino acid sequence of the hybrid pre-protein consisting of the signal peptide and the amino-terminal half of the B. macerans protein and the carboxyl-terminal half of the B. amyloliquefaciens protein. The EcoRV site used for splicing is indicated. An arrow indicates the signal peptidase cleavage site. The sequence of the 3 ' non-coding region is not shown. b, Diagram of the bgl-H2 gene and details of the fusion region. SP: signal peptide. 


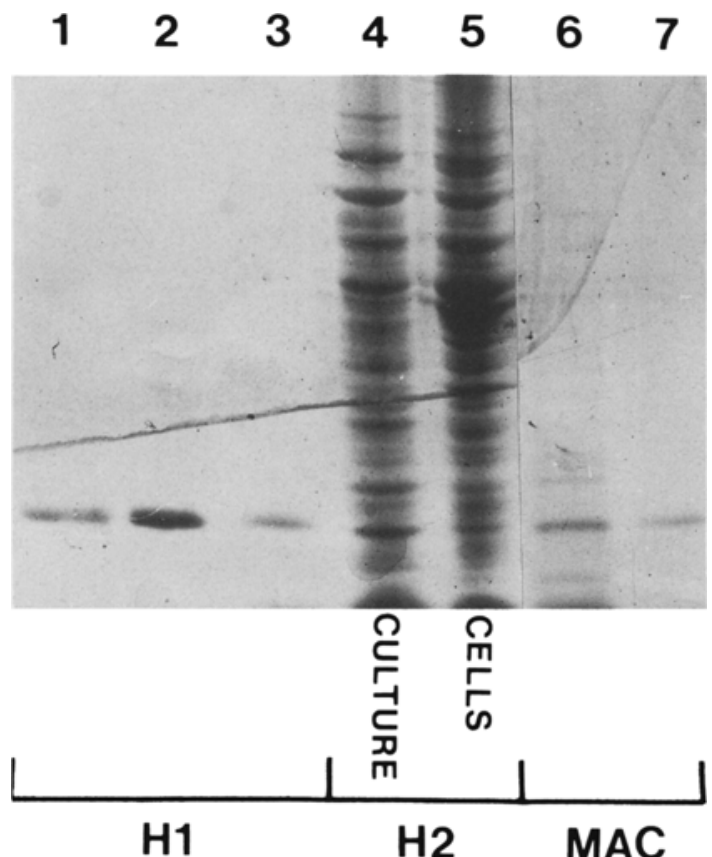

Figure 5. SDS-PAGE of samples containing hybrid $\beta$-glucanases and $B$. macerans $\beta$-glucanase. Lanes 1-3: $2 \mu \mathrm{g}, 5 \mu \mathrm{g}$, and $1 \mu \mathrm{g}$ purified $\beta$-glucanase $\mathrm{H} 1$. Lane 4: sample containing $50 \mu \mathrm{g}$ supernatant protein and lane 5: $100 \mu \mathrm{g}$ cell extract of E. coli cells transformed by pUC-H2. Lane 6: $2 \mu \mathrm{g}$ of partially purified $B$. macerans $\beta$-glucanase. Lane 7: $1 \mu \mathrm{g}$ of purified B. macerans B-glucanase.

$10 \mathrm{~mm} \mathrm{CaCl}$. The reaction was initiated by addition of $0.1 \mathrm{ml}$ enzyme solution and incubation was at $37^{\circ} \mathrm{C}$ for $20 \mathrm{~min}$. The reaction was stopped by addition of $0.5 \mathrm{ml}$ 3,5-dinitrosalicylic acid and the amount of reducing sugars were measured using the reagent formulation outlined by MILLER (22). Specific activity is expressed as $\mu$ mole glucose released per min and $\mathrm{mg}$ of protein. Method B: Alternatively, azobarley $\beta$-glucan was used as substrate for analysis of $\beta$-glucanase activity (20). The buffers employed were: 40 mM sodium acetate, $\mathrm{pH} 3.6-5.6$; $40 \mathrm{mM}$ potassium-sodium phosphate, $\mathrm{pH} \mathrm{6-8}$; 40 mM Tris- $\mathrm{HCl}, \mathrm{pH}$ 8.4-8.8.

Plate assay: E. coli cells were incubated on solid medium containing $0.2 \%(w / v)$ lichenan. Staining with $0.2 \%(\mathrm{w} / \mathrm{v})$ Congo red reveals a clearing zone around colonies expressing $\beta$-glucanase.

\subsection{Containment}

All experiments involving recombinant DNA were carried out under BL1 laboratory conditions and waste containing biological material was autoclaved.

\section{RESULTS}

\subsection{Hybrid $\beta$-glucanase genes}

The fragment for the expression of the bgl-H 1 recombinant gene is shown in Figure 3 . The construct contains 469 bp of the flanking region, $75 \mathrm{bp}$ encoding the signal peptide, and $321 \mathrm{bp}$ encoding the amino-terminal half of the $\mathbf{B}$. amyloliquefaciens $\beta$-glucanase. This $865 \mathrm{bp}$ DNA stretch is fused in frame to the carboxylterminal half coding region as well as $51 \mathrm{bp}$ of the 3'-flanking region of the $\beta$-glucanase gene from B. macerans.

The other recombinant gene, bgl-H2, (Fig. 4) consists of 99 bp of the 5 -flanking region, $75 \mathrm{bp}$ encoding the signal peptide and 315 bp encoding the amino-terminal half of the $B$. macerans $\beta$-glucanase. This $489 \mathrm{bp}$ fragment is fused in frame to a $321 \mathrm{bp}$ DNA segment encoding the

Table I. Synthesis of $\beta$-glucanase in E. coli cells transformed with pUC13-H1 and pUC19-H2, respectively

\begin{tabular}{lll}
\hline plasmid & $\begin{array}{l}\beta \text {-glucanase activity }\left(\mu \text { mole glucose } \mathrm{ml} \text { culture }{ }^{-1} \cdot \text { min }^{-1}\right) \\
\text { supernatant }\end{array}$ \\
\hline pUC13-H1 & 67.5 & 7.0 \\
pUC19-H2 & 0.06 & n.d. \\
\hline n.d. = not detectable & & \\
Cells were grown in tryptone-yeast medium with intensive shaking for $20 \mathrm{~h}$ at $37^{\circ} \mathrm{C}$. After centrifugation $(5000 \times \mathrm{g}$, \\
$10 \mathrm{~min})$, the supernatant was used directly for assay of enzyme activity. The pellet was washed, resuspended in \\
$40 \mathrm{~mm}$ acetate, pH 6 and sonicated on ice $4 \times 20 \mathrm{sec}$ with a Branson Sonifier and clarified by centrifugation.
\end{tabular}


Table II. Kinetic parameters of hybrid and parental ß-glucanases

\begin{tabular}{lllll}
\hline$\beta$-glucanase & hybrid 1 & hybrid 2 & macerans & amyloliquefaciens \\
\hline $\begin{array}{l}\text { Relative } \mathrm{V}_{\max } \\
\quad \text { Glucan }\end{array}$ & 1 & & & \\
$\quad$ Lichenan & 0.77 & 0.88 & 0.73 & 1 \\
$\mathrm{~K}_{\mathrm{m}}(\mathrm{mg} / \mathrm{ml})$ & & & & 1.1 \\
$\quad$ Glucan & 1.25 & 1.67 & 0.83 & 1.25 \\
$\quad$ Lichenan & 1.05 & 1.54 & 0.67 & 1.67 \\
Specific activity & 3722 & $10.4^{*}$ & 5030 & $1330(5)$ \\
$\left(\mu\right.$ mole glucose $\left.\mathrm{mg}^{-1} \cdot \mathrm{min}^{-1}\right)$ & & & & \\
\hline
\end{tabular}

- enriched cell extract

carboxyl-terminal half of B. amyloliquefaciens $\beta$-glucanase and approximately $1.5 \mathrm{~Kb} 3$ '-flanking region.

Plasmid constructions were analysed by restriction enzyme digests, DNA sequence determination around splice junctions, or both.

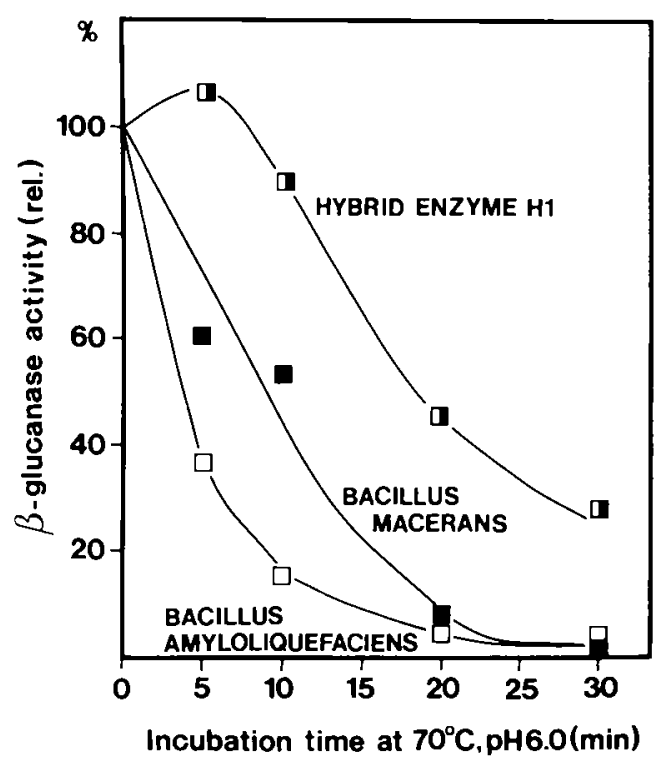

Figure 6. Activity of Bacillus hybrid $\beta$-glucanase $\mathrm{HI}$ and parental enzymes in crude extracts (2.7) from transgenic E. coli cells after incubation for various lengths of time at $70^{\circ} \mathrm{C}, \mathrm{pH} 6.0$. Activity is expressed as per cent of activity at time 0 .

\subsection{Analysis of hybrid gene products}

Hybrid $\beta$-glucanase genes were expressed in $E$ coli cells and the hybrid $\beta$-glucanase $H 1$ was purified according to the procedure used for $B$ macerans $\beta$-glucanase (7). By SDS-PAGE it was confirmed that the $\beta$-glucanase migrated as on $\epsilon$

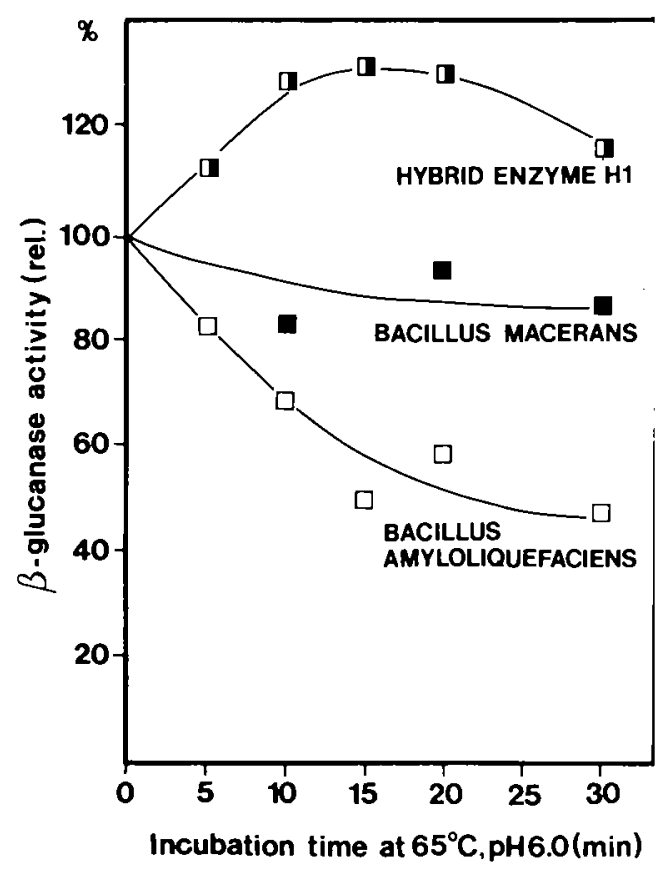

Figure 7. Activity of hybrid Bacillus B-glucanase HI and parental enzymes in crude extracts (2.7) from transgenic E. coli cells after incubation for various lengths of time at $65^{\circ} \mathrm{C}, \mathrm{pH} 6.0$. Activity is expressed as per cent of activity at time 0 . 


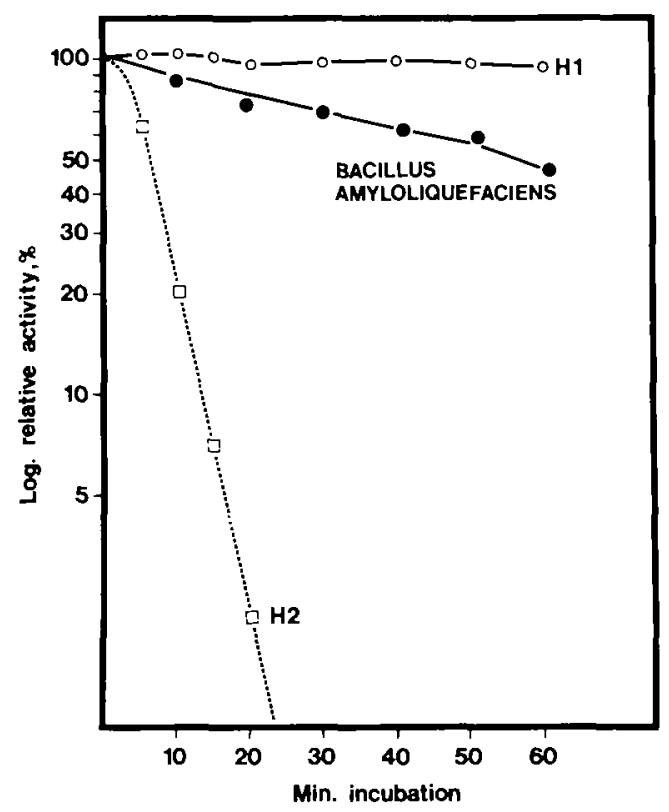

Figure 8. Time course of thermoinactivation of Bacillus hybrid $\beta$-glucanases $\mathrm{H} 1$ and $\mathrm{H} 2$ at $65^{\circ} \mathrm{C}, \mathrm{pH} 5.5$ in comparison with the enzyme of $B$. amyloliquefaciens.

The purified amyloliquefaciens and $\mathrm{Hl}$-enzymes were dissolved at a concentration of $1 \mu \mathrm{g} \cdot \mathrm{ml}^{-1}$ in 40 $\mathrm{mm} \mathrm{Na}$-acetate, $\mathrm{pH} 5.5,10 \mathrm{mM} \mathrm{CaCl}_{2}$ and $50 \mu \mathrm{g} \cdot \mathrm{ml}^{-1}$ bovine serum albumine. The $\mathrm{H} 2$-enzyme preparation was dissolved at a protein concentration of 0.75 $\mathrm{mg} \cdot \mathrm{ml}^{-1}$ in an identical buffer. Samples were withdrawn periodically and assayed for residual $\beta$-glucanase activity.

Coomassie blue staining band (Fig. 5). The yield of hybrid enzyme $\mathrm{H} 2$ was only $1 \%$ of that obtained of $\mathrm{H} 1$ and too low to produce a chromatographically pure preparation (Table l). The specific activity of $\beta$-glucanase $\mathrm{Hl}$ was determined to be $3700 \mu$ mole glucose $\mathrm{mg}^{-1} \cdot \mathrm{min}^{-1}$ which is comparable to the specific activity of $\beta$-glucanases from Bacillus IMET B376 (1330 $\mu$ mole glucose $\left.\mathrm{mg}^{-1} \cdot \mathrm{min}^{-1}\right)(6)$ and from $B$. macerans $\left(5030 \mu\right.$ mole glucose $\left.\mathrm{mg}^{-1} \cdot \mathrm{min}^{-1}\right)$. For characterization of the bgl-H2 gene product an enriched extract with a specific activity of 10.4 $\mu$ mole glucose $\mathrm{mg}^{-1} \cdot \mathrm{min}^{-1}$ was used (Table II).

\subsection{Substrate specificity}

Hybrid enzymes $\mathrm{H} 1$ and $\mathrm{H} 2$ degraded barley $(1-3,1-4)-\beta$-glucan as well as lichenan and the

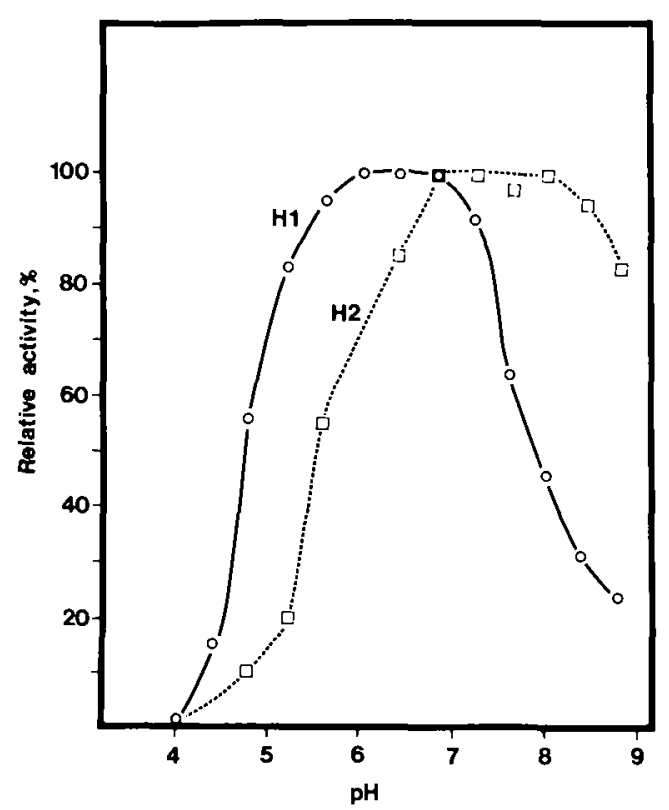

Figure 9. The pH dependance of the activity of Bacillus hybrid $\beta$-glucanases $\mathrm{H} 1$ and $\mathrm{H} 2$.

The reactions were carried out with $1-6 \mu \mathrm{g} \mathrm{H} 1$ $\beta$-glucanase and 7-70 $\mu \mathrm{g} \mathrm{H} 2 \beta$-glucanase preparation in the following buffers: $40 \mathrm{mM} \mathrm{Na}$-acetate, pH 3.6-5.6; $40 \mathrm{~mm}$ K/Na phosphate, pH 6-8 and $40 \mathrm{~mm}$ Tris- $\mathrm{HCl}$, pH 8.4-8.8. Activity was determined with the Biocon assay using azo-barley $\beta$-glucan as substrate (19).

relative $\mathrm{V}_{\max }$ values determined with both substrates did not differ significantly (Table II). The $K_{m}$ values for both hybrid proteins were determined using either barley $\beta$-glucan or lichenan as substrate. The obtained values were very similar (Table II).

\subsection{Kinetics of thermoinactivation of B-glucanases}

Initial information about the thermostability of hybrid $\beta$-glucanases in comparison with the parental enzymes from B. amyloliquefaciens and $B$. macerans was obtained by measuring the time course of thermoinactivation of $\beta$-glucanase in crude extracts from E. coli cells transformed with plasmids pUC13-H1, pUC19-H2, pEG1 and pUC13-Mac encoding $\mathrm{H} 1, \mathrm{H} 2, \mathrm{~B}$. 


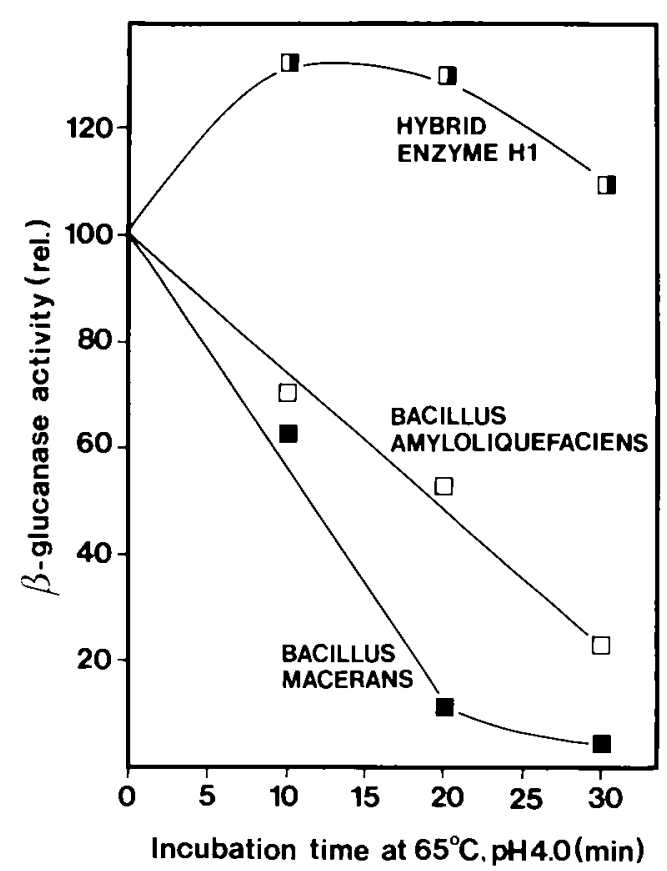

Figure 10. Activity of Bacillus hybrid $\beta$-glucanase $\mathrm{H}$ I and parental enzymes in crude extracts (section 2.7) from transgenic $E$. coli cells after incubation for various length of time at $65^{\circ} \mathrm{C}, \mathrm{pH} 4.0$.

Activity is expressed as per cent of activity at time 0 .

amyloliquefaciens and B. macerans recombinant $\beta$-glucanase, respectively. The samples (usually in the concentration range $0.3-1 \mathrm{mg}$ / $\mathrm{ml}$ ) were incubated in $10 \mathrm{~mm} \mathrm{CaCl}, 40 \mathrm{~mm}$ Na-acetate, pH 6.0 at $70{ }^{\circ} \mathrm{C}$ and samples were removed periodically for determination of residual $\beta$-glucanase activity (Fig. 6). The results of this analysis reveal that the half-life of $\mathrm{HI}$ $\beta$-glucanase is significantly higher $(50 \%$ inactivation in $18.5 \mathrm{~min}$ ) than half-lives of the parental enzymes from $B$. amyloliquefaciens ( 4 $\mathrm{min})$ and $\mathrm{B}$. macerans $(9 \mathrm{~min})$. The $\mathrm{H} 2 \beta$-glucanase underwent thermoinactivation with a half-life less than $2 \mathrm{~min}$ and is thus more heat-labile than the parental enzymes. When the analysis was carried out at $65^{\circ} \mathrm{C}$ (Fig. 7) the hybrid enzyme $\mathrm{HI}$ was stable for more than 30

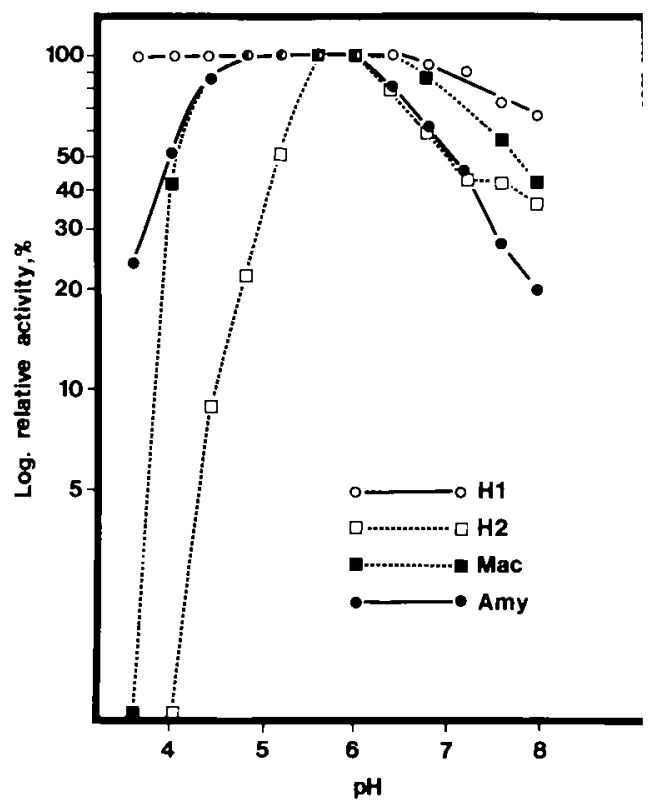

Figure 11. The pH dependence of stability of Bacillus $\beta$-glucanase at $55^{\circ} \mathrm{C} .2 \mu \mathrm{g}$ of hybrid $\beta$-glucanase $\mathrm{Hl}$. $375 \mu \mathrm{g}$ protein of hybrid $\beta$-glucanase $\mathrm{H} 2$ preparation $2 \mu \mathrm{g}$ of $\mathrm{B}$. macerans $\beta$-glucanase or $10 \mu \mathrm{g}$ of $\mathrm{B}$. amyloliquefaciens $\beta$-glucanase were tested with $10 \mathrm{~mm}$ $\mathrm{CaCl}$ and $50 \mu \mathrm{g} \cdot \mathrm{ml}^{-1}$ bovine serum albumin in $40 \mathrm{~mm}$ $\mathrm{Na}$-acetate buffer adjusted to the indicated $\mathrm{pH}$ values in the range of 3.6 to 5.6 or in $40 \mathrm{~mm} \mathrm{~K}$-Na phosphate buffer adjusted to the indicated $\mathrm{pH}$ values in the range 6.0 to 8.0. After incubation for $1 \mathrm{~h}$ at $55^{\circ} \mathrm{C}$ the residual activity was measured with method A (section 2.7).

min while the half-life of the enzyme from $B$. amyloliquefaciens was about $25 \mathrm{~min}$ and that of B. macerans intermediate between the two. Purified $\mathrm{H} 1$ enzyme was stable for more than 1 h when analyzed at $65^{\circ} \mathrm{C}, \mathrm{pH} 5.5$, whereas partially purified $\mathrm{H} 2$ enzyme was irreversibly thermoinactivated within $20-25 \mathrm{~min}$ (Fig. 8). A time course for the inactivation of purified enzyme from B. amyloliquefaciens is given for comparison. Consistently, the hybrid enzyme $\mathrm{H} 1$ was significantly activated when tested after 5 min at 65 to $70{ }^{\circ} \mathrm{C}$ (Figs. 6 and 7).

\subsection{Effect of pH on enzymatic activity and stability of hybrid $\beta$-glucanases}

The $\mathrm{pH}$ for optimal enzymatic activity of 
hybrid $\beta$-glucanase $\mathrm{H} 1$ was $\mathrm{pH}^{\prime 5} 5.6$ to 6.6 , while that for hybrid enzyme $\mathrm{H} 2$ was $\mathrm{pH} 7.0$ to 8.0 (Fig. 9). For comparison, the pH optimum for enzymatic activity of the $\beta$-glucanases from $B$. amyloliquefaciens and $\mathrm{B}$. macerans was $\mathrm{pH} 6.0$ to 7.0 and pH 6.0 to 7.5 , respectively (results not shown). Figure 9 also shows that hybrid enzyme $\mathrm{H} 1$ retains $50 \%$ of its activity at $\mathrm{pH} 4.8$ and that $\mathrm{H} 2$ retains $50 \%$ of its activity at $\mathrm{pH} 5.6$. The corresponding values for the parental enzymes are pH 5.2 (B. amyloliquefaciens) and pH 5.5 (B. macerans).

Another characteristic is enzyme stability as a function of $\mathrm{pH}$. When the time course of thermoinactivation of the $\beta$-glucanases in crude extracts was followed at $\mathrm{pH} 4.0$ and a temperature of $65^{\circ} \mathrm{C}$ the hybrid enzyme $\mathrm{H} 1$ was stable for more than $30 \mathrm{~min}$ while the $\beta$-glucanase from B. amyloliquefaciens had a half-life of 20 min and that of B. macerans of only 12 min (Fig. 10). This feature was further examined for

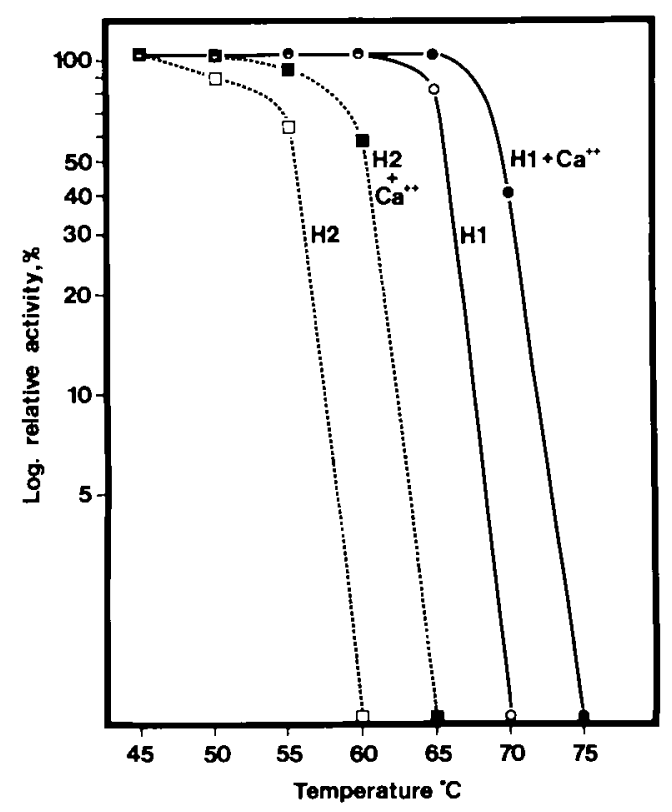

Figure 12. Improvement of thermal stability of Bacillus hybrid $\beta$-glucanases with $\mathrm{CaCl}_{2}$.

$0.1 \mu \mathrm{g}$ Bacillus hybrid enzyme $\mathrm{H} 1$ or $750 \mu \mathrm{g}$ hybrid enzyme $\mathrm{H} 2$ preparation was dissolved in $1 \mathrm{ml} 40 \mathrm{mM}$ $\mathrm{Na}$-acetate buffer pH 5.5 with or without $50 \mathrm{mM} \mathrm{CaCl}_{2}$ and supplemented with $50 \mu \mathrm{g} \cdot \mathrm{ml}^{-1}$ bovine serum albumine. After incubation for $30 \mathrm{~min}$ at the indicated temperatures the residual activity was determined. hybrid and parental $\beta$-glucanases by incubation at $55^{\circ} \mathrm{C}$ for $1 \mathrm{~h}$ in the range $\mathrm{pH} 3$ to 9 , followed by determination of residual enzymatic activity (Fig. 11). One can see that $\beta$-glucanase $\mathrm{H} 1$ is stable from below $\mathrm{pH} 3.6$ up to 7.0, while $\beta$-glucanase $\mathrm{H} 2$ has a very narrow $\mathrm{pH}$ range of stability between pH 5.6 to 6.0 . Both parental $\beta$-glucanases are unstable below $\mathrm{pH} 4.8$ and above $\mathrm{pH} 6.0$ (B. amyloliquefaciens) or $\mathrm{pH} 6.4$ (B. macerans).

\subsection{The effect of $\mathrm{Ca}^{++}$on thermostability}

The effect of $\mathrm{Ca}^{++}$on the stability of hybrid $\beta$-glucanases was analyzed in a $30 \mathrm{~min}$ assay at pH 5.5 and temperatures ranging from $45^{\circ} \mathrm{C}$ to $75^{\circ} \mathrm{C}$. From the results of this analysis, shown in Figure 12, the temperature for $50 \%$ inactivation in a 30 min assay can be deduced. It is clear that $\mathrm{Ca}^{++}$ions have a stabilizing effect on both hybrid enzymes. The temperatures for $50 \%$ inactivation increase about $5{ }^{\circ} \mathrm{C}$ for both hybrid $\beta$-glucanases in the presence of $10 \mathrm{mMCa}^{++}$. The same stabilising effect of $\mathrm{Ca}^{++}$ions is also found for the two parental enzymes.

\section{DISCUSSION}

In recent years a number of attempts have been made to construct improved versions of existing biologically active proteins to make them better suited for industrial processes and to widen their range of application. Much interest has focused on increasing the thermostability of enzymes. It has been proposed that the thermostability of enzymes may be enhanced by single amino acid substitutions that decrease the entropy of unfolding (19). Several tentative rules for increasing the thermostability of proteins have been established $(1,15,24)$ but precise predictions for changes of structure to function relationships remain elusive (see ref. 26 for review).

The most thermostable $(1-3,1-4)-\beta$-glucanase known to date is produced by $B$. macerans (5). However, at temperatures exceeding $65^{\circ} \mathrm{C}$ and at $\mathrm{pH}$ values of 4.5 to 5.5 , which is typical for industrial mashing in a brewery, the $B$. macerans $\beta$-glucanase is rapidly inactivated. In the present paper we have described the construction of two 
hybrid genes encoding recombinant Bacillus (1-3,1-4)- $\beta$-glucanases. These hybrid genes were constructed by reciprocal exchanges of the amino-terminal and carboxy-terminal halves of the $\beta$-glucanase encoding genes from B. amyloliquefaciens and B. macerans via a common EcoRV restriction endonuclease site located in a homologous region in the central part of the two genes. The hybrid $\beta$-glucanase genes were expressed in E. coli cells and the biochemical properties of the hybrid enzymes were analysed.

The level of $\beta$-glucanase expression from the hybrid genes in E. coli differed dramatically. Cells harbouring the $\mathrm{H} 1$ gene (containing 5 ' half of the amyloliquefaciens gene) had about 1000 fold more $\beta$-glucanase activity than cells carrying the $\mathrm{H} 2$ construction, but the enzyme kinetic parameters $K_{m}$ and relative $V_{\max }$ for two substrates of the enzymes are similar. It is therefore most likely that this difference is caused by variation in the rate of initiation of transcription of the two hybrid genes. Possibly, the 99 nucleotides upstream from the $B$. macerans initiation codon in $\mathrm{H} 2$ constitute too short a sequence to promote efficient initiation of mRNA transcription, in contrast to the 469 nucleotides present in front of the initiation codon of $\mathrm{H} 1$. It cannot be excluded, however, that the $\mathrm{H} 2$ protein is degraded or inactivated in E. coli at a much higher rate than the $\mathrm{H} 1$ protein.

Compared to the parental enzymes the hybrid proteins exhibit novel biochemical properties such as different pH-optima, thermostability and differences in $\mathrm{pH}$ tolerance. The $\mathrm{H} 1$ protein is of special interest for the brewing industry since in this protein the tolerance to lower $\mathrm{pH}$ and a low $\mathrm{pH}$ optimum of enzymatic activity has been combined with a thermostability exceeding that of the $\mathrm{B}$. macerans $\beta$-glucanase at high $\mathrm{pH}$. The $\mathrm{pH}$ optimum and especially the $\mathrm{pH}$ tolerance has been shifted to more acidic conditions and the thermostability surpasses that of both parental enzymes over the entire tested $\mathrm{pH}$ range.

In vitro recombination of homologous genes giving rise to hybrid proteins retaining the biological activity of the parental molecules is not unprecedented. STREuLl et al. (28) as well as WECK and coworkers (31) constructed hybrid human leukocyte interferon genes. Some of the hybrid interferons extended the host cell range for protection against Vesicular Stomatitis anc encephalomyocarditis virus. Thus the AD hy. brids combining portions of interferons $A$ and $D$ elicited significantly greater antiviral activities than either parental molecule on mouse L-929 cells, human Hela cells and primary rabbi1 kidney cells. Heat stability, pH stability and antigenic specificity were the same in the hybrid and parental interferon molecules.

The hybrid Bacillus $\beta$-glucanase $(\mathrm{H} 1)$ described in this presentation is unique in combining and improving two industrially important enzyme characteristics within the same molecule. Further improvement of the hybrid $\beta$-glucanase may be accomplished by site directed or random mutagenesis in specific regions of the gene.

The superiority of the hybrid Bacillus $\beta$-glucanase $\mathrm{H} 1$ can be considered a case of molecular heterosis or hybrid vigour. Heterosis, the concept of superiority of heterozygotes in many genes, as recognized by G.H. SHULL in 1908 (27), forms the basis for the immensely successful breeding programs for hybrid corn and other agricultural plants. Subsequently, monohybrid heterosis or overdominance was discovered, implying that an individual heterozygous for a pair of alleles is superior to both homozygotes. The best known case in humans is the advantage provided by heterozygosity for the sickle-cell hemoglobin $\mathrm{Hb}^{\mathrm{s}} \beta$ allele in protection against the malaria parasite. The amino acid substitution of one glutamate residue by valine in the $S$. hemoglobin causes it to polymerize at low oxygen tension leading to severe, often fatal anemia. The hybrid hemoglobin consisting of 2 molecules $\mathrm{HbA}$ and 2 molecules $\mathrm{HbS}$ can function normally except at very low oxygen tension, when hemoglobin polymerization causes the erythrocytes to attain a sickle shape. Oligomeric hybrid glutamate dehydrogenase molecules in Neurospora have been found by FINCHAM (10) to combine properties of the homooligomeric counterparts and may turn out in some cases to be superior, i.e. display heterosis. In the hybrid enzyme described in the present report a more stable enzyme has been achieved through in vitro recombination leading to a novel polypeptide chain combining the amino-terminal half 
of one glucanase with the carrboxyl-terminal half of another highly homologous glucanase. Conceivably, such intragenic heterosis could also result from crossing over in merozygotes of bacteria or from meiotic crossing over in diploid or polyploid eukaryotic species. One can pose the question to what extent it plays a role in the evolution of enzyme molecules.

\section{ACKNOWLEDGEMENTS}

BIRTE SVENSSON is thanked for stimulating discussions, and INGRID KAEPPLER and KARINA BOSERUP are thanked for skilful technical assistance. We are grateful to NINA RASMUSSEN and ANN-SOF STEINHOLTZ for art work and HANNE THEM NIELSEN and LISE TRILLOT for typing the manuscript. This work was supported by the Biomolecular Action Programme of the Commission of the European Community with contract No. BAP-0091-DK to D. voN WeTtSTEIN and H.G. SARX.

\section{REFERENCES}

1. Argos, P., M.G. Rossmann, V.M.Grau, H. Zuber \& J.D. TRATSCHIN: Thermal stability and protein structure. Biochemistry 18, 5698-5703 (1979)

2. Bolivar, F., R.L. Rodriguez, P.J. Greene, M.C. BetlaCh, H.L. HeYNEKer, H.W. BOYER: Construction and characterization of new cloning vechicle. II. A multipurpose cloning system. Gene 2, 95-113 (1977)

3. BORRISS, R: Purification and charcterization of an extracellular beta-glucanase from Bacillus IMET B376. Z. Alg. Mikrobiologie 21, 7-17 (1981)

4. BORRISS, R. \& KL. SCHROEDER: $\beta-1.3-1.4-\mathrm{glu}-$ canase in sporeforming microorganisms. V. The efficiency of $\beta$-glucanase in reducing the viscosity of wort. Zbl. Bakt. II Abt. 136, 330-340 (1981)

5. BORRISS, R. \& J. ZEMEK: $\beta$-1.3-1.4-glucanase in sporeforming microorganisms. IV. Properties of some Bacillus $\beta$-glucan hydrolases. Zbl. Bakt. II. Abt. 136, 63-69 (1981)

6. BORRISS, R., H. BAEUMLEIN \& J. HOFEMEISTER: EXpression in Escherichia coli of a cloned $\beta$-glucanase gene from Bacillus amyloliquefaciens. Appl. Microbiol. Biotechnol. 22, 63-71 (1985)

7. BORRISS, R., R. MANTEUfFEL \& J. HOFEMEISTER: Molecular cloning of a gene coding for thermostable beta-glucanase from Bacillus macerans. J. Basic Microbiol. 28, 3-10 (1988)
8. BRADFORD, M.M.: A rapid and sensitve method for the quantitation of microgram quantities of protein utilizing the principle of protein dye binding. Anal. Biochem. 72, 248-254 (1976)

9. Cantwell, B.A. \& D.J. MCConnell: Molecular cloning and expression of Bacillus subtilis $\beta$-glucanase gene in Escherichia coli. Gene 23, 211-219 (1983)

10. Fincham, J.R.S.: Allelic complementation reconsidered. Carlsberg Res. Commun. 42, $421-430$ (1977)

11. Godfrey, T.: On comparison of key characteristics of industrial enzymes by type and source. Godfrey, T. \& J. Reichelt (eds) Industrial Enzymology. MacMillan, London, p. 466 (1983)

12. HaNAHAN, D.: Techniques for transformation of $E$. coli. In: DNA Cloning, vol 1. A practical approach. D.M. Glover ed., IRL Press, Oxford, pp. 109-135 (1985)

13. Hattori, M. \& Y. SaKaKI: Dideoxy sequencing method using denatured plasmid templates. Anal. Chem. 152, 232-238 (1986)

14. Hofemeister, J., A. KURTZ, R. Borriss \& J. KNOWLES: The $\beta$-glucanase gene from Bacillus amyloliquefaciens shows extensive homology with that of Bacillus subtilis. Gene 49, 177-187 (1986)

15. Imanaka, T., M. Shibazaki \& M. Takagi: A new way of enhancing the thermostability of proteases. Nature 324, 695-697 (1986)

16. LAEMMLI. U.K: Cleavage of structural proteins during the assembly of the head of bacteriophage T4. Nature 227, 680-685 (1970)

17. LEDERBERG, E.M. \& S.N. COHEN: Transformation of Salmonella typhimurium by plasmid deoxyribonucleic acid. J. Bacteriol. 119, 1072-1074(1974)

18. LoI. L.. P.A. BARTON \& G.B. FINCHER: Survival of barley $(1 \rightarrow 3,1 \rightarrow 4)$ - $\beta$-glucanase isoenzymes during kilning and mashing. J. Cereal Sci. 5, 45-50 (1987)

19. Matthews. B.W., H. Nicholson \& W.J. BeCKTEL: Enhanced protein thermostability from site-directed mutations that decrease the entropy of unfolding. Proc. Natl. Acad. Sci. 84, 6663-6667 (1987)

20. MCCleary, B.V.: Soluble, dye-labeled polysaccharides for the assay of endohydrolases. Methods Enzymol. 160, 74-86 (1988)

21. MCFadden, G.I., B. Ahluwalia. A.E. Clarke \& G.B. FINCHER: Expression sites and developmental regulation of genes encoding $(1 \rightarrow 3,1 \rightarrow 4)$ - $\beta$-glucanases in germinated barley. Planta $173,500-508$ (1988)

22. Miller, G.L.: Use of dinitrosalicylic acid reagent for determination of reducing sugars. Analytical Chemistry 31, 426-428 (1959)

23. Murphy, N., D.J. McConnell \& B.A. Cantwell: 
The DNA sequence of the gene and genetic control sites for the excreted $B$. subtilis enzyme $\beta$-glucanase. Nucleic Acids Res. 12, 5355-5367 (1984)

24. QUerol, E. \& A. Parilla: Tentative rules for increasing the thermostability of enzymes by protein engineering. Enzyme Microb. Technol. 9, 238-244 (1987)

25. Rickes, E.L., E.A. Ham, E.A. Moscatelli \& W.H. OTT: The isolation and biological properties of a beta-glucanase from Bacillus subtilis. Arch. Biochem. Biophys. 69, 371-375 (1962)

26. SHaw, W.V.: Protein engineering. The design, synthesis and characterization of factitious proteins. Biochem. J. 246, 1-17 (1987)

27. SHULL, G.H.: Beginnings of the heterosis concept. In: J.W. Gowen ed., Heterosis, Iowa State College Press, Ames, Iowa 1952

28. Streuli, M. A Hall, W. Boll, W.E. Stewart II, S Nagata \& C. Weissmann: Target cell specifity of two species of human interferon-alpha produced in Escherichia coli and of hybrid molecules derived from them. Proc. Natl. Acad. Sci. USA, 2848-2852 (1981)

29. THOMSEN, K.K.: Mouse $\alpha$-amylase synthesized by Saccharomyces cerevisiae is released into the cutture medium. Carlsberg Res. Commun. 48, 545555 (1983)

30. Vanish-Perron, C., J. Vieira \& J. Messing: Improved M13 phage cloning vectors and host strains: nucleotide sequences of the M13 mp18 and pUC19 vectors. Gene 33, 103-119 (1985)

31. WeCK, P., T. APPERSON, N. STEBBing, H.M. SHEPHARD, D.V. GOEDDEL.Antiviral activities of hybrids of two major human leukocyte interferons. Nucleic Acids Res. 9, 6153-6165 (1981)

32. Zhang, H., R. SCholl, J. Browse \& C. SOMMERVILLE: Double stranded sequencing as a choice for DNA sequencing. Nucleic Acids Res. 16, 1220 (1988) 